\title{
Development and application of biological technologies in fish genetic breeding
}

\author{
XU Kang, DUAN Wei, XIAO Jun, TAO Min, ZHANG Chun, LIU Yun \& LIU ShaoJun* \\ Key Laboratory of Protein Chemistry and Fish Developmental Biology of Ministry of Education of China, College of Life Sciences, \\ Hunan Normal University, Changsha 410081, China
}

Received September 23, 2014; accepted November 6, 2014; published online January 15, 2015

\begin{abstract}
Fish genetic breeding is a process that remolds heritable traits to obtain neotype and improved varieties. For the purpose of genetic improvement, researchers can select for desirable genetic traits, integrate a suite of traits from different donors, or alter the innate genetic traits of a species. These improved varieties have, in many cases, facilitated the development of the aquaculture industry by lowering costs and increasing both quality and yield. In this review, we present the pertinent literatures and summarize the biological bases and application of selection breeding technologies (containing traditional selective breeding, molecular marker-assisted breeding, genome-wide selective breeding and breeding by controlling single-sex groups), integration breeding technologies (containing cross breeding, nuclear transplantation, germline stem cells and germ cells transplantation, artificial gynogenesis, artificial androgenesis and polyploid breeding) and modification breeding technologies (represented by transgenic breeding) in fish genetic breeding. Additionally, we discuss the progress our laboratory has made in the field of chromosomal ploidy breeding of fish, including distant hybridization, gynogenesis, and androgenesis. Finally, we systematically summarize the research status and known problems associated with each technology.
\end{abstract}

fish genetic breeding, genetic improvement, biological method, traits, new variety

Citation: Xu K, Duan W, Xiao J, Tao M, Zhang C, Liu Y, Liu SJ. Development and application of biological technologies in fish genetic breeding. Sci China Life Sci, 2015, 58: 187-201, doi: 10.1007/s11427-015-4798-3

Fish is high in protein, unsaturated fatty acids, vitamins, and microelements, so it is an important component of a high-protein, low-calorie diet. Recent outbreaks of mad cow disease, foot-and-mouth disease, and bird flu suggest that fish is one of the safer animal-based foods for human consumption. Unfortunately, however, the increased demand for fish has resulted in rapid depletion of fish stocks throughout the world. Concurrently, water resources are becoming scarcer. Given these trends, there is an urgent need to improve the efficiency and sustainability of the aquaculture industry. To address this, researchers have used a variety of methods to produce new varieties that have desirable traits such as rapid growth, high meat quality, and

*Corresponding author (email: 1sj@hunnu.edu.cn) stress resistance.

The various approaches to genetic enhancement can be divided into three categories: selective breeding, integration breeding, and modification breeding. Selective breeding involves selection and breeding of individuals in a population that have desirable traits. Integration breeding involves the combination of two or more groups to obtain a mix of desirable traits from the donors. Modification breeding involves the creation of new genetic traits.

Selective breeding can be further divided into traditional selective breeding and molecular marker-assisted selective breeding. The classical approach to traditional selective breeding is to choose and breed only individuals that exhibit desirable characteristics for one or multiple traits such as growth rate, meat quality, and stress resistance. Methods 
that yield all-female and all-male groups by treatments with hormones, temperature, or other factors are also included in this category. The research and application of molecular markers associated with functional genes in genetic breeding can also be classified as molecular marker-assisted selection.

The essence of integration breeding is to produce individuals whose genetic materials are altered from those of the parents. For this purpose, hybridization, hydrostatic pressure, colchicine treatment and other biological, physical, or chemical methods are used to obtain hybrid or polyploid individuals. During the processes of distant hybridization, gynogenesis, and androgenesis, chromosome ploidy is reflected in the gametes and zygotes. Application of nucleus transplantation and stem cells transplantation (SCT) results in the recombination of genetic materials, and these methods are categorized into integration breeding. It is worth noting that distant hybridization can not only generate heterosis in new varieties, but also result in the formation of diploid or tetraploid hybrid strains, in which both the females and males are fertile. Under these conditions it is possible to form a new species.

Modification breeding involves the creation of transgenic fish by the transfer of genetic material from a donor to a recipient via micromanipulation.

The purpose of integration breeding and modification breeding is to alter the genotype and phenotype of offspring. Selection breeding can be used subsequent to integration or modification breeding to ensure the persistence and emphasis of desirable inherited characteristics.

\section{Fish genetic breeding}

\subsection{Selection breeding techniques}

Directional filtering of traits is an important and indispensable step in genetic breeding programs. Recently, research has focused on methods to rapidly and efficiently screen for important economic traits. Advances in the fields of genetics, molecular biology, and other biological techniques have resulted in a shift from single traditional selective breeding to more diverse selective breeding methods. The following discussion summarizes selective breeding based on the divisions between traditional selective breeding, markerassisted selection, genomic technology breeding, and monosex breeding.

\subsubsection{Traditional selective breeding}

In fish, traditional selective breeding is the classical method of genetic breeding. The primary objective is to screen and select for desirable genetic traits in individuals or groups. Common methods of traditional selective breeding include population selective breeding, pedigree selective breeding, parental selective breeding, and integrated selective breeding. Additionally, best linear unbiased prediction (BLUP) has been used for rainbow trout (Oncorhynchus mykiss) [1], coho salmon (Oncorhynchus kisutch) [2], black sea bass (Dicentrarchus labrax L.) [3] and other species.

Selective breeding has been successfully applied to enhance desirable traits in multiple species, including rainbow trout [1], silver carp (Hypophthalmichthys molitrix) [4], channel catfish (Ictalurus punctutatus) [5], and so on. In early 1919, Embody and Hyford [6] used selective breeding to increase survival from $2 \%$ to $69 \%$ in brook trout (Salvelinus fontinalis) infected with furunculosis. Similarly, a number of selected strains of rainbow trout have been bred for desirable traits, such as fast growth, increased fecundity, and early spawning. In China, traditional selective breeding is frequently applied in freshwater fish breeding. For example, purse red carp (Cyprinus carpio var. wuyuanensis) were selected using a combination of population selection and family selection methods [7]. Xingguo red carp (Cyprinus carpio var singuonensis.) were obtained using population selection breeding [7] and Molong carp (Cyprinus carpio var Molong.) were obtained using a combination of comprehensive and directional selection [7]. A targeted group breeding method was used to obtain Gansu golden trout (Oncorhynchus mykiss) [8]. Additionally, "Pujiang No.1" blunt snout bream (Pujiang No.1 Megalobrama amblycephala) [9], new Gift tilapia (GIFT, Oreochromis niloticus) [10] and Matsuura mirror carp (Cyprinus carpio Songpu carp) [7] were also obtained by selective methods. Among marine fish, bastard halibut (Paralichthys olivaceus) [11], large yellow croaker (Pseudosciaen acrocea) [12], etc. [13] were bred using selection methods and the BLUP breeding method was used for the selection of turbot (Scophthalmus maximus) [14].

\subsubsection{Molecular marker-assisted breeding}

Molecular markers are a direct reflection of the genetic diversity at the DNA level. As such, these markers have a number of applications, including the identification of population structure or commercially important traits $[15,16]$, identification and cloning of genes [17], construction of genetic maps [18], analysis of genetic relationships [16], prediction of heterosis and molecular-assisted selection breeding [19]. A number of methods have been developed to obtain molecular markers, including Variable Number of Tandem Repeats (VNTR), Random Amplified Polymorphic DNA (RAPD), DNA Amplification Fingerprinting (DAF), Single Nucleotide Polymorphisms (SNP), Amplified Fragment Length Polymorphism (AFLP), Inter-simple Sequence Repeat (ISSR), Simple Sequence Repeat (SSR), Single-strand Conformation Polymorphism (SSCP), Restriction Fragment Length Polymorphism (RFLP) and Sequenced Characterized Amplified Region Marker (SCAR), and others [20].

The development of molecular marker has improved the accuracy and efficiency of selection for specific traits. As a result, molecular-assisted breeding technologies are in- 
creasingly used in aquaculture. For example, genetic linkage maps have been constructed for zebrafish [21], medaka [22], pufferfish [23], swordtail fish (Xiphophorus helleri) [24], three thorns fish (Gasterosteus aculeatus) [25], rainbow trout [26], Nile tilapia [27] and several other economically important fish species. These genetic linkage maps have been used to direct selective breeding for many traits $[28,29]$. In China, researchers have completed genome sequencing in common carp and have subsequently developed genetic linkage maps to identify quantitative trait loci (QTLs) [30], including those linked to muscle fiber related traits and cold resistance, using a BAC library [31]. BAC libraries have been constructed for grass carp (Ctenopharyngodon idellus) [32], blunt snout bream, red crucian carp (Carassius auratus var.), silver crucian carp [33], half smooth tongue sole (Cynoglossus semilaevis Gunther) [34] and others. These BAC libraries lay the foundation for the physical map building and genome sequencing [31].

\subsubsection{Genome-wide selective breeding technology}

Recently, researchers have decoded the genome of several fish species, including zebrafish (Danio rerio), medaka (Oryzias latipes), pufferfish (Takifugu rubripes), green pufferfish (Tetraodon nigroviridis), Nile tilapia (Oreochromis niloticus), channel catfish (Ictalurus punctatus), rainbow trout, Atlantic salmon (Salmo salar), bass (Dicentrarchus labrax), and Atlantic cod (Gadus morhua) [31,35-37]. The availability of these genomic data has opened up a number of opportunities to advance basic research and develop commercial applications. For example, genetic linkage maps and molecular genetic marker techniques have been used to explore the location of genes associated with growth, sex decision, disease resistance, and other traits. Additionally, quantitative trait loci are used to design DNA markers for assisted breeding technology. In 2010, Chinese researchers obtained the whole genome sequences of half smooth tongue sole [38], Pacific oysters (Crassostrea gigas) [39], large yellow croaker, epinephelus bleekeri (Epinephelus bleekeri), common carp (Cyprinus carpio) [40], and bastard halibut [31]. In 2011, researchers at the Chinese Academy of Sciences Institute of Aquatic Organisms and other research institutions also started whole genome sequencing of bighead carp (Aristichthys nobilis), grass carp, and silver carp (Hypophthalmichthys molitrix), species that form part of the "four famous fish" in China [31]. Additionally, our laboratory has basically completed the comprehensive genome sequencing of red crucian carp. The data from this latter effort are critical to improving our understanding of allotetraploid heredity, and will also provide important insights into ways to advance molecular genetic breeding in cyprinidae. At the same time, our laboratory has started the whole genome sequencing of Erythroculter ilishaeformis, which is one of the original parents of a new type of hybrid bream that is obtained by our laboratory and has been approved by National Certification
Committee for Aquatic Varieties. The obtaining of the genome sequencing of Erythroculter ilishaeformis is beneficial for explaining the molecular mechanism of heterosis and other traits of this new type of hybrid bream. In summary, genomic information allows for more rapid and complete understanding of economically important performance traits and provides a basis for the development of new varieties for aquaculture.

More recently, next-generation sequencing (NGS) has been used in our laboratory to obtain transcriptome data from different tissues in red crucian carp, common carp (Cyprinus carpio L.), blunt snout bream, Xenocypris davidi bleeker, grass carp, and some hybrid fish (e.g., allotetraploid and allotriploid). These transcriptome data are essential for comprehensive analyses of the genetic characteristics of cyprinid fish and also can be used to obtain SSR and SNP markers which are helpful for seeking specific molecular markers for selective breeding.

\subsubsection{Breeding by controlling single-sex groups}

Sex-specific differences in morphology and physiological function are relatively common in animals. For example, male and female individuals of several fish species exhibit differences in growth rate, maturation age, reproductive pattern, body color, and body size. Aquaculturists can exploit these differences by controlling the sex of fry, typically by sex reversal, to conduct monosex cultivation.

There are two types of sex determination mechanisms in fish: chromosomal and environmental. In chromosomal sex determination, the sex is determined by genes and the sex of an embryo depends on its allosome composition or other sex-determined genes. Under environmental sex determination, sex is influenced by external factors such as temperature, humidity, and $\mathrm{pH}$ [41].

Since the 1950s, researchers and culturists have tested the utility of hormone treatments to alter fish sex in a number of species, including Oryzias latipes, Carassius auratus auratus, Carassius aruatus, Cyprinus carpio, Brachydanio rerio, Onchorynchus mykiss, Salmo salar, Oncorhynchus kisutch, O. tshawytscha, Oreochromis mossambicus, Epinephelus akaara, Oreochromis niloticus, Poecilia reticulates Peters, Mollienisia velifera, Xiphophorous hellerii, Mugil cephalus, Epinephelus coioides, E. tauvina, and Carassius auratus gibelio [41-43].

The mechanism of action and efficacy of these treatments varies among sex hormones. Among androgens, $17 \alpha$-methyltestosterone is most widely used as it can be added to the feed relatively easily. Conversely, 17 $\beta$ estradiol and oestrone are the most commonly used estrogens. In one of the earliest experiments, Yamamoto [44] used estrogen to transform male goldfish (Carassius auratus auratus) and medaka into females, which were then crossed with wild male fish to generate YY males. In 1975, Guerrero tested the efficacy of adding methyltestosterone to the feed to convert sex in Oreochromis aureus [45]. In our 
laboratory, Liu et al. [46] noted that feeding fry with estradiol for an extended period resulted in conversion of males to females with only remnants of testis-like tissue on the ovary surface in leather moustache catfish (Clarias lazera). Conversely, feeding with methyltestosterone (MT) induced sex reversed male and hermaphrodites fish with female genotype. The authors subsequently acquired all-female offspring by self-fertilization of bisexual fish, which helped determine the genetic pattern of sex choice (the type of 우 $\mathrm{XX}-\mathrm{o}^{\top} \mathrm{XY}$ ) in Leather moustache catfish and raised a new means of obtaining homozygotes $[46,47]$.

Chen et al. [48] successfully transformed gynogenetic Cyprinus carpio into functional male fish by feeding with methyltestosterone, then crossed these functional male fish with pure red common carp and generated all-female common carp. In addition, our laboratory [49] fed gynogenetic Carassius auratus cuvieri fry with MT and obtained functional sex-reversed male individuals. Crossing these individuals with common female $C$. auratus cuvieri and female allotetraploid C. aruatus (우) $\times$ Cyprinus carpio ( $\overbrace{}^{\top})$, we obtained all-female diploid $C$. auratus cuvieri and all-female triploid fish. The population of all-female diploid C. auratus cuvieri was crossed with male allotetraploid fish to generate triploid carp. Using this approach, we were able to eliminate the need to artificially remove male individuals, resulting in reduced costs for culturists [50]. Liu et al. [33] obtained functional XY female Pelteobagrus fulvidraco using hormone-mediated reversal, then used gynogenesis to generate $\mathrm{XX}, \mathrm{XY}$ and YY individuals. On this basis, Wang et al. isolated two pairs of $\mathrm{Y}$ and $\mathrm{X}$ chromosome-specific markers from yellow catfish (Pelteobagrus fulvidraco) by AFLP and SCAR screening, which then were applied on screening YY super-male individuals and thereby developed a $\mathrm{Y}$ - and $\mathrm{X}$-specific allele marker-assisted sex control technical route for cultivating all-male populations [31,51,52]. Following this technical route, all-male Pelteobagrus fulvidraco with stable genetic traits has been approved as a novel variety "yellow catfish all-male No. 1" by National Certification Committee for Aquatic Varieties, because yellow catfish males grow faster than females, and generate difference in individual ultimate size about 2-3 fold.

\subsection{Integration breeding technologies}

\subsubsection{Cross breeding}

The cross breeding (hybridization) of two species is one of the most basic methods of integrating desirable traits (e.g., growth rate, disease resistance). Hybridization aims to get improved new varieties of better growth rate, reproduction rate, disease resistance, yield and quality through integrating excellent parental characters, which plays an important role in fish breeding improvement and production value.
The process of hybridization is divided into two categories, distant and close hybridization, based on the parental genetic relationship. Distant hybridization characterizes crosses between parents that differ by species or higher classifications. Close hybridization characterizes crosses between parents of the same species, but different strains, different varieties, different ecological types, or different populations of individuals.

Because of the close evolutionary relationship between parents, close hybridization generally results in fertile hybrid progeny, so is commonly used in hybrid breeding. The most representative example of close hybridization in fish is the carp [53]. The intraspecific hybridization of carp has occurred throughout the world, resulting in multiple geographic strains or domesticated strains [53,54]. In China, researchers have developed 15 superior carp strains of common carp (e.g., Feng carp, black dragon carp, Xingde carp and so on $[7,53,55]$. In our laboratory, we have developed Yue carp, and more recently, we have obtained two new hybrid fish from crossing combinations of Japanese crucian carp and red crucian carp. The new strains not only integrate many desirable characteristics of their parents, exhibiting significant heterosis, but also have significantly improved fertilization and hatching rates ${ }^{1)}$. Using a combination of hybridization and selection breeding, we obtained Hefang crucian carp which was produced by crossing female Japanese crucian carp (Carassius auratus cuvieri) with male red crucian carp (Carassius auratus red var.), a strain that has rapid growth, a desirable shape, and improved meat quality. We are in the process of having this strain certified as a national farmed fish (Figure 1). At the same time, there is controversy about the biological categories of Carassius auratus cuvieri and Carassius auratus red var., and put them into two different species, so hybridization between these two fish can also be recognized as distant hybridization. In addition to carp hybrids, researchers at the Shanghai Fisheries University and other institutions have used mixed hybrid methods to obtain Gift tilapia, which has both growth and size advantages over the parent varieties [56].

The filial generation of close hybridization places a limi-

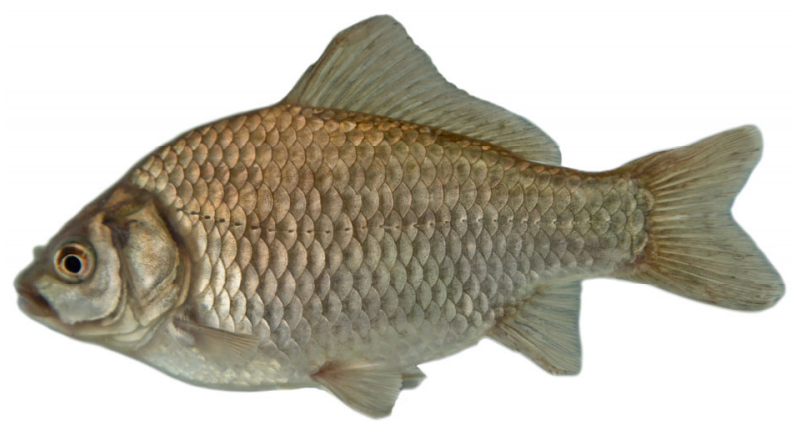

Figure 1 Carassius auratus cuvieri (우)×Carassius auratus red var. (ő).

1) Liu SJ, Liu Y, Xiao J, Luo KK, Tao M, Zhang C, Zhao RR. Hybridization between Japanese crucian carp and red crucian carp. PRC Patent, CN2010 1 0291988.3, 2010-9-26 
tation on the available genetic variability. As a result, there is currently increased interest in distant hybridization. Distant hybridization involves a much larger gene pool so has a greater potential for breeding new groups and even a new species [57]. Between 1558 and 1980, 1,080 species from 56 families of fish were used in hybrid tests [58]. In the 1950s, Chinese researchers began to experiment with distant hybridization, using fish from three orders (Cypriniformes, Perciformes, Siluriformes), seven families (Cyprinidae, Serranidae, Cichidae, Sparidae, Siluridae, Clariidae, Bagridae), more than 40 species, and $>100$ hybrid combinations, with the majority involving Cyprinidae.

Distant hybridization has been successfully achieved between different orders, including between M. amblycephala (우) in Cypriniformes and Siniperca chuatsi ( $\left.\sigma^{\star}\right)$ in Perciformes, and between Hypophthalmichthys molitrix (우) in Cypriniformes and Pagrosomus major ( $\sigma^{\top}$ ) in Perciformes. Fingerlings were successfully hatched from these crosses, but these were not subsequently reared for production [59]. Inter-familial hybridization has been reported between perciform cichlids $O$. aureus (우) and Siniperca chuatsi ( $\left.0^{\star}\right)$, with fingerling survival rates of $0.3 \%-0.5 \%$, but this level is not adequate for production [59]. In contrast, the hybrid offspring of $H$. molitrix and Aristichys nobilis have higher survival and are less aggressive than their parents [60]. Similarly, the filial generations of O. mossambicus (우) and $O$. niloticus $\left(\sigma^{\top}\right)$ have a faster growth rate than the parents [61]. Last, the hybrid offspring of Morone sexatilis (우) and Morone chrysops $\left({ }^{\top}\right)$ males exhibit obvious heterosis [62]. In recent years, the domestic scientists processed much interspecific hybridization of fish in Cyprinidae, Paralichthyidae [63], Siluridae, Sparidae, Cichlid, Percichthyidae, etc. [59].

Hybrid combinations are often chosen between different species, different genus and even different subfamilies in Cyprinidae fish. In Cyprinidae fish, common carp, crucian carp, black carp (Mylopharyngodon piceus), grass carp, bighead carp, silver carp, blunt snout bream, Xenocypris davidi Bleeker, Topmouth Culter (Erythroculter ilishaeformis), etc. are often used in hybrids. Over the past several years, our laboratory has carried out numerous hybridization experiments between different subfamilies such as Carassius auratus red Var. (우)×Elopichthys bambusa ( $\overbrace{}^{\top})$ [61] and other combinations; between different genus such as Carassius auratus red Var. (우) $\times$ Cyprinus carpio Xiangjiangnensis (ठ) [64] and other combinations (Table 1).

The utilization of distant heterosis of hybridization is primarily limited to the $F_{1}$ generation in fish at present. However, the ability to maintain heritable traits for multiple generations will be important to realize the full benefits of heterosis from distant hybridization. To address this need, we obtained an allotetraploid hybrid strain by crossing Carassius auratus red Var. (우) with Cyprinus carpio Xiangjiangnensis $\left({ }^{\top}\right)$ [57,64], and obtained allotetraploid hybrid groups $(4 n=148)$ from the $\mathrm{F}_{1}$ of Carassius auratus red Var. (우)×Megalobrama amblycephala (ठ). After continued breeding we acquired an autotetraploid hybrid group from the $\mathrm{F}_{2}$ and their self-crossed progenies $\left(\mathrm{F}_{2}-\mathrm{F}_{9}, 4 n=200\right)$ [69]. The characteristics of these two tetraploid hybrid strains are heritable and they can be used in the production of triploid fish [61]. Similarly, from the hybridization between Megalobrama amblycephala ( 우) $\times$ Erythroculter ilishaeformis (ठ) and Erythroculter ilishaeformis (우)× Megalobrama amblycephala ( $\left.\mho^{\top}\right)$, we obtained fertile male and female individuals in the $F_{1}$ and $F_{2}$ generations, which allowed development of an $\mathrm{F}_{3}$ generation. Subsequently, by using female diploid offspring of the cross between Megalobrama amblycephala (우) $\times$ Erythroculter ilishaeformis ( $\left.\sigma^{\top}\right)$ and backcrossing with male Megalobrama amblycephala, we produced a new type of hybrid bream that has rapid growth (20\% greater than for M. amblycephala), increased disease resistance, improved meat quality, and desirable shape characteristics.

Parent selection is an important component in the success of hybridization experiments. A number of factors must be taken into account, including the chromosome number of the parents, phylogenetic relationships, reproductive behaviors, feeding, appearance, and growth rates. It is important to obtain the different ploidy fish offspring with different special traits and through breeding to develop a variety of different types of excellent fish strains. After the experiments of above hybridization (Table 1), the importance of the combination parental choice is showed ubiquitously. Meanwhile, each design for a good combination of distant hybridization research is a systematic project, and needs long-term unremitting efforts.

\subsubsection{Nuclear transplantation}

Nuclear transplantation involves the transplantation of a donor-cell nucleus into an enucleated unfertilized egg by micromanipulation. The new cell will continue to split and develop as usual. This technology can be used to break the reproductive isolation among species and change the mode of breeding. Tong [70] was the first to test the possibility of nuclear transplantation between conspecifics using the goldfish and Rhodeus sinensis Gunther, and firstly demonstrated that nucleus of cell in mid-blastocyst of teleostean had totipotency to guide the enucleated eggs developing into embryos and adults.

After transplantation, the success of embryo development is determined by the totipotency of the transplanted nucleus and the degree of fusion with the recipient cytoplasm. Chen et al. [71] transplanted the renal cell nuclei of triploid crucian carp into the enucleated oocytes of diploid crucian carp by way of serial nuclear transfer, and obtained fertile cloned fish. The authors verified the totipotency of the differentiated somatic cells. Lee et al. [72] demonstrated that somatic 
Table 1 Distant hybridization experiment in Cyprinidae

\begin{tabular}{|c|c|c|c|c|c|}
\hline \multicolumn{2}{|c|}{ Genetic relationship } & Serial number & Hybridized combination & Food habit combination & Generation number \\
\hline \multirow{10}{*}{ Subfamily } & \multirow{6}{*}{$\begin{array}{l}\text { The parents with } \\
\text { equal chromosomal } \\
\text { numbers }\end{array}$} & 1 & $\begin{array}{l}\text { Megalobrama amblycephala }(\text { 우 }) \times \\
\text { Xenocypris davidi Bleeker }\left({ }^{\top}\right)[65] \\
(2 n=48) \times(2 n=48)\end{array}$ & herbivority ×omnivory & $\mathrm{F}_{1}-\mathrm{F}_{2}$ \\
\hline & & 2 & $\begin{array}{l}\text { Xenocypris davidi Bleeker }(\text { 우 }) \times \\
\text { Megalobrama amblycephala }\left({ }^{\nwarrow}\right)[59] \\
(2 n=48) \times(2 n=48)\end{array}$ & omnivory $\times$ herbivority & $\mathrm{F}_{1}$ \\
\hline & & 3 & $\begin{array}{c}\text { Ctenopharyngodon idellus }(\text { 우 }) \times \\
\text { Megalobrama amblycephala }\left({ }^{\star}\right)[66] \\
(2 n=48) \times(2 n=48)\end{array}$ & herbivority $\times$ herbivority & $\mathrm{F}_{1}$ \\
\hline & & 4 & $\begin{array}{c}\text { Xenocypris davidi Bleeker }(\text { 우 }) \times \\
\text { Erythroculter ilishaeformis }\left(\text { ठ }^{\top}\right)[59] \\
\quad(2 n=48) \times(2 n=48)\end{array}$ & omnivory $\times$ predacity & $\mathrm{F}_{1}$ \\
\hline & & 5 & $\begin{array}{l}\text { Erythroculter ilishaeformis }(\text { 우 }) \times \\
\text { Xenocypris davidi } \text { Bleeker }\left({ }^{\top}\right)[59] \\
\quad(2 n=48) \times(2 n=48)\end{array}$ & predacity $\times$ omnivory & $\mathrm{F}_{1}$ \\
\hline & & 6 & $\begin{array}{c}\text { Megalobrama amblycephala }(\text { 우 }) \times \\
\text { Elopichthys bambusa }\left({ }^{\nwarrow}\right)[59] \\
(2 n=48) \times(2 n=48)\end{array}$ & herbivority $\times$ predacity & $\mathrm{F}_{1}$ \\
\hline & \multirow{4}{*}{$\begin{array}{l}\text { The parents with } \\
\text { unequal chromo- } \\
\text { somal numbers }\end{array}$} & 1 & $\begin{array}{c}\text { Carassius auratus red Var. ( 우 }) \times \\
\text { Megalobrama amblycephala }\left({ }^{\top}\right) \text { [67] } \\
(2 n=100) \times(2 n=48)\end{array}$ & omnivory $\times$ herbivority & $\mathrm{F}_{1}-\mathrm{F}_{9}$ \\
\hline & & 2 & $\begin{array}{c}\text { Carassius auratus red Var. (우) } \times \\
\text { Xenocypris davidi Bleeker }\left({ }^{\star}\right) \text { [59] } \\
(2 n=100) \times(2 n=48)\end{array}$ & omnivory $\times$ omnivory & $\mathrm{F}_{1}$ \\
\hline & & 3 & $\begin{array}{l}\text { Carassius auratus red Var. (우) } \times \\
\text { Erythroculter ilishaeformis }\left(0^{\star}\right)[68] \\
(2 n=100) \times(2 n=48)\end{array}$ & omnivory $\times$ predacity & $\mathrm{F}_{1}$ \\
\hline & & 4 & $\begin{array}{c}\text { Carassius auratus red Var. ( 우) } \times \\
\text { Elopichthys bambusa }\left(\text { ( }^{\star}\right) \text { [59] } \\
(2 n=100) \times(2 n=48)\end{array}$ & omnivory $\times$ predacity & $\mathrm{F}_{1}$ \\
\hline \multirow{3}{*}{ Genus } & \multirow{3}{*}{$\begin{array}{l}\text { The parents with } \\
\text { equal chromosomal } \\
\text { numbers }\end{array}$} & 1 & $\begin{array}{c}\text { Carassius auratus red Var. }(\text { 우 }) \times \\
\text { Cyprinus carpio }\left({ }^{\star}\right)[64] \\
(2 n=100) \times(2 n=100)\end{array}$ & omnivory $\times$ omnivory & $\mathrm{F}_{1}-\mathrm{F}_{24}$ \\
\hline & & 3 & $\begin{array}{l}\text { Megalobrama amblycephala }(\text { 우 }) \times \\
\text { Erythroculter ilishaeformis }\left(0^{\top}\right)[59] \\
\qquad(2 n=48) \times(2 n=48)\end{array}$ & herbivority $\times$ predacity & $\mathrm{F}_{1}-\mathrm{F}_{3}$ \\
\hline & & 4 & $\begin{array}{l}\text { Erythroculter ilishaeformis }(\text { 우 }) \times \\
\text { Megalobrama amblycephala }(\text { (屯) }[59] \\
(2 n=48) \times(2 n=48)\end{array}$ & predacity $\times$ herbivority & $\mathrm{F}_{1}-\mathrm{F}_{3}$ \\
\hline
\end{tabular}

cells from zebrafish maintained totipotency even after long-term culture.

Yan et al. [73] suggested that nucleoplasm hybridization by nuclear transplantation can be used to facilitate crosses between two species that are distantly related, though the success of the cross is correlated with the evolutionary distance. If true, this ability may be a function of the evolutionary history of fish within the animal line or a low level of "incompatibility" among fishes with respect to their ability to hybridize. Yu et al. [74] demonstrated that the evolutionary relationship between the donor and receptor influenced the ease of nuclear transplantation. The survival rate of nucleoplasm hybridized common carp and crucian carp was higher than the hybrids of grass carp and blunt snout bream or silver carp and blunt snout bream.

Although there are still some problems associated with nuclear transplantation in fish (e.g., low survival, physiological deficiency, immune deficiency), researchers have used this approach to successfully conduct nuclear transplants between different genera, subfamilies, families and orders. For example, Yan et al. [75] transplanted nuclei from blastula cells of crucian carp, tilapia, and grass carp into the enucleated eggs of carp, blunt snout bream, and carp, respectively. The authors obtained crucian carp nucleoplasm hybrids, which were of significant value for breeding as their excellent traits in faster growth rate, higher protein content and lower fat content. Additionally, Yu et al. [76] transplanted nuclei from the blastula cells of carp, tilapia, and grass carp into the non-enucleated eggs of crucian carp, bream, and goldfish, respectively. Lin et al. [77] transplanted nuclei from the head kidney cells of crucian carp, Cirrhinus molitorella, and tilapia into the enucleated unfertilized eggs of carp. Using a combination of androgenesis and nuclear transplantation, Liu et al. [78] obtained five diploid loaches (Misgurnus anguillicaudatus) that developed from arrhenokaryon and could be bred for 2-7 
months.

Researchers in China have made a number of advances in the use of nuclear transplantation in fish. However, a number of problems still persist, such as low survival rate of nucleoplasm hybrid fish, physiological deficiencies, and immune defects in some fish. Thus, there is a need for further study of this approach and a better understanding of the mechanisms controlling embryo development. Additionally, the means of detection of nuclear transplantation require improvement.

\subsubsection{Transplantation of germline stem cells and germ cells}

Fish germ cell transplantation is a form of cell engineering technology that can be used to regulate fish reproduction. Primordial germ cell (PGC) transplantation technology was first applied successfully in chickens [79], and has since been used in chickens, goats, and pigs [80-82]. In fish, Takeuchi et al. [83] developed the first PGC transplantation system in 2003. Hong et al. [84] successfully used adult fish testis to develop a normal medaka spermatogonial stem cell line (SG3) that had the ability to produce spermatozoids. This not only confirmed that adult spermatogonial cells had the ability to form cell lines, but also provided a new way to obtain germline stem cells and simplified the fish germ cell transplantation program. In 2006, Okutsu et al. [85] developed a spermatogonial transplantation system of rainbow trout. In 2009, Yi et al. [86,87] established haploid ES cell lines from medaka gynogenetic haploid embryos, and then created the semi-cloned female medaka which shows normal fertility by using the semi-cloning technology. Currently, most germ cells used for transplantation are derived from juvenile and adult males in a process that typically involves harvest of PGCs in spermatogonial stem cells or spermatogonia. Fish reproductive cell transplant methods can be divided into three categories: intraspecific transplantation of fish germ cells, interspecific transfer of fish reproductive cells, and transplantation of germ cells into a sterile triploid receptor.

The intraspecific transplantation of fish germ cells is primarily used in studies of fish germ cells and reproductive development mechanisms. Nobrega et al. [88] observed spermatogenesis and oogenesis after transplant of zebrafish spermatogonial stem cells to male and female zebrafish, respectively, thereby demonstrating that germ cell differentiation is affected by the environment. In 2004, Takeuchi et al. [89] transplanted rainbow trout PGCs to O. masou and obtained $O$. masou gametes that developed normally. Similarly, Majhi et al. [90] transplanted germ cells from Odontesthes bonariensis to mature $O$. hatcheri and obtained viable sperm within 6 months of the transfer. In these instances, the parent PGCs reached sexual maturity more rapidly and differentiated to sperm faster than the donor's own in the heterologous receptor.

Using an alternate approach, Okutsu et al. [91] obtained
O. masou that could produce $100 \%$ rainbow trout offspring following transplant of homozygous orange rainbow trout mutant germ cells into sterile triploid $O$. masou.

Fish reproductive stem cell and germ cell transplantation methods have opened up new possibilities for the protection and restoration of endangered germplasm resources and genetic breeding. However, there remains a need for more theoretical and practical understanding of the mechanisms to decrease the development time between laboratory and commercial application.

\subsubsection{Artificial gynogenesis and androgenesis}

(1) Artificial gynogenesis technology. Gynogenesis refers to a form of reproduction in which the eggs are activated by sperm and the development of zygotes is controlled by matrilineal genes. Gynogenesis can be divided into natural and artificial gynogenesis. To date, natural gynogenesis has been documented in at least 10 species, including Poecilia formosa, Menidia clarkhubbsi, and Misgurnus anguillicaudatus [92]. It should be noted that Carassius auratus gibelio were cultivated by Chinese aquaculture researchers according to the reproductive mode of natural gynogenesis in Heilongjiang Fangzheng silver crucian carp [93]. Our laboratory has obtained bisexual fertile natural gynogenetic red crucian carp from the offspring of red crucian carp (우) and $M$. amblycephala $\left(\delta^{\star}\right)$. These natural gynogenetic red crucian carps have been stably bred for many generations. The formation of bisexual fertile natural gynogenetic red crucian carp will allow development of a new strain of Carassius auratus [94].

Artificially induced gynogenesis refers to a breeding technique that uses inactivated sperm to activate eggs. The development of zygotes is controlled by maternally derived genes. For fish species with female homogamety, artificially induced gynogenetic progeny are all females. In the process of artificial gynogenesis, heterogenous spermatozoas are usually used to induce the development of eggs. Artificial gynogenesis can purify genetic material of gametes and result in new genetic material and new genetic traits as a result of allogynogenesis. In summary, gynogenesis can be used to control the sex of fish and obtain pure inbred lines to purify and rejuvenate the fish species.

Artificially induced gynogenesis has been carried out in common carp, carassius auratus gibellio, grass carp, rare minnow (gobiocypris rarus), blunt snout bream, large yellow croaker, sterlet (Acipenser ruthenus), tilapia, rainbow trout, Atlantic halibut (Hippoglossoides platessoides), European seabass (Dicentrarchus labrax), south flounder (Paralichthys lethostigma), turbot (Scophthalmus maximus), bass (Perca fluviatilis), Esox masquinongy and >100 other fish species [92,95]. Gynogenetic strains of red sea bream (Pagrosomus major), rainbow trout, weever (Lateolabrax japonicus), calico salmon (Oncorhynchus keta), olive flounder (Paralichthys olivaceus) have subsequently been used in production settings [96-102]. 
Our group has developed gynogenetic strains from natural origin red crucian carp, Carassius auratus cuvieri, goldfish, common carp, orange ornamental carp (Cyprinus carpio), grass carp, Erythroculter ilishaeformis, Xenocypris davidi Bleeker, and artificially cultivated strains including tetraploid hybrids of common carp with red crucian carp and tetraploid hybrids of red crucian carp with blunt snout bream [103-107]. We have developed gynogenetic strains of red crucian carp, Japanese crucian carp, and goldfish following activation using heterogenous sperms (M. amblycephala). These gynogenetic strains have a higher survival rate and are easily identified. The combination of artificial gynogenesis and sex reversal technology sets the stages for the production of all-female diploids and triploids [103,104]. It is worth noting that Zhang et al. [105] have built disease-resistant gynogenetic strains of grass carp by the activation of inactivated sperm of tetraploids. These gynogenetic grass carp demonstrate that gynogenesis can be used to obtain all-female individuals that have desirable genetic traits. Lived artificial gynogenetic fish have strong resistance and tolerance, which is due to the process of selection, such as cold shock and the inactivated genetic material of sperm. The survived fish that underwent the adversity were easy to obtain traits that resist harsh conditions. Liu et al. [106] have obtained diploid gynogenetic offspring by using the diploid eggs from allotetraploid hybrids by gynogenesis without chromosome-doubling treatment. Through long- term research, we established a strain of diploid gynogenetic hybrids $\left(\mathrm{G}_{1}-\mathrm{G}_{8}\right)$ that were able to produce fertile diploid eggs. This strain is not only a model for research into the mechanism of diploid gamete formation, but also can provide high-quality diploid eggs for developing new types of modified tetraploids. Our laboratory has obtained improved allotetraploid hybrids by fertilizing diploid eggs from the diploid gynogenetic hybrids with diploid sperm from allotetraploid hybrids, an important step in the mass production of improved triploid fish.

The artificial induction of gynogenesis in fish has a wide range of applications from theoretical research to commercial production. However, the methods used to date have low survival rates and complex identification of gynogenetic fish. Recent improvements in methods of inactivating sperm and doubling egg chromosomes have improved the survival rate of gynogenetic fish. Furthermore, research suggests that using sperm from distant fish can improve the survival rate of gynogenetic fish and simplify their identification. We have obtained gynogenetic crucian carp using sperm from blunt snout bream. This variety has higher survival rate than gynogenetic crucian carp created using common carp sperm, and is more easily identified [103].

(2) Artificial androgenesis technology. In contrast to gynogenesis, androgenesis involves the use of genetically inactivated eggs and normal sperm to form a "zygote". The "zygote" develops into an individual that is primarily under the control of nuclear genetic material from the sperm. The steps involved in the artificial induction of androgenesis and gynogenesis are similar, and include the inactivation of gynogenesis genetic material and the induction of diploid androgenesis. This method has been used for the rapid establishment of pure lines, to determine mechanisms of sex determination, to create unisexual populations, and for the protection of endangered fish [92].

Natural androgenesis individuals are rare in nature but occur in the hybrid offspring common carp (female) and grass carp (male) [108]. The artificial induction of androgenesis fish has primarily been attempted in O. mykiss, Platichthys flesus, Salvelinus japonicus, Oreochromis niloticus, Danio rerio, Oncorhynchus masou, Ctenopharyngodon idellu, Esox reticulatu, Misgurnus anguillicaudrus, Pelteobagrus fulvidraco, and so on [92,109-111]. It is worth noting that because male tilapia grows more rapidly than female tilapia, androgenesis could be used to rapidly obtain super-male individuals with a male nucleus (YY). Then, crossing with normal female (XX) hybrids would yield all-male tilapia (XY) offspring.

To date, haploid sperm has been rarely used to induce artificial androgenesis in fish for industry. The primary limiting factor is the difficulty in inactivating the DNA in the egg and the negative impact on the sperm nucleus genome resulting from artificial doubling of androgenesis individual embryos and later life activities that lead to a low rate of individual survival in androgenesis. The use of tetraploid fish, with two sets of chromosomes in the diploid sperm, for artificial androgenesis would yield diploid androgenetic offspring without the need for chromosome-doubling treatment, thereby improving the success rate of androgenesis. Indeed, researchers have carried out androgenesis using diploid sperm that was produced by artificial tetraploid rainbow trout and natural tetraploid loach without chromosome-doubling treatment, and obtained diploid androgenetic fish that have higher survival rate than those when using haploid sperm [112-114].

We have successfully obtained bisexual fertile diploid androgenetic fish $\left(\mathrm{A}_{0}\right)$ using diploid sperm produced by allotetraploid hybrids, without male nuclear chromosome-doubling treatment. Diploid androgenetic fish were self-crossed to obtain bisexual fertile tetraploids. When compared with ordinary allotetraploid hybrids, the new-type tetraploid fish exhibited significant growth advantages and increased disease resistance [115,116]. Additionally, using diploid sperms produced by autotetraploid males, we obtained super-male diploid fish from offspring that can produce unreduced diploid sperm. Subsequent crossing with haploid or diploid eggs yields all-male triploid and tetraploid fish, respectively. The all-male tetraploid fish can be used for the subsequent production of triploid fish, eliminating the artificial selection steps needed to produce all-male fish, reducing the cost and improving breeding efficiency. 


\subsubsection{Polyploid breeding}

Polyploids contain three or more complete chromosome sets, which are widespread in plants and animals and are important for speciation [117]. Polyploid breeding refers to doubling cell genomes by artificial or natural mutagenesis to produce polyploid individuals, and then selected and fostered by persons to meet requirements. Fish genomes have greater plasticity, and could be doubled, so research about fish polyploidy is flourishing.

Triploids typically exhibit rapid growth, strong resistance, and high yield, so are of high economic value [118]. Additionally, the majority of allotriploid fish are infertile, which reduces issues associated with diversion of energy to gametic growth, mixing of genetic lines, and interbreeding with wild stocks.

Triploids are primarily produced using one of two methods: by direct induction or by the hybridization of tetraploid parent groups and hybrid triploids to produce diploid groups. Using the first method, it is difficult to guarantee a high proportion of triploids in offspring. In contrast, the second method yields more predictable results.

Currently, the methods used to induce polyploidy fall into one of three categories: biological, physical, and chemical. Biological methods include hybridization, nuclear transfer, and cell fusion. Physical methods include temperature shock, hydrostatic pressure, and high-salt and highalkaline electric shock treatment. Chemical methods involve the use of different chemicals (e.g., cytochalasin, caffeine, polyethylene glycol, colchicine, 6-dimethyl aminopurine) to induce embryonic polyploidy.

Physical and chemical methods artificially induce polyploidy work by inhibiting the exclusion of the first or second polar body in the oocytes or inhibiting the first cleavage of zygotes [117]. Gui et al. [119] succeeded in inducing triploid Carassius auratus transparent colored var. by hydrostatic pressure. Similarly, Chen et al. [120] used hydrostatic pressure to prevent loss of the second polar body of zygotes and obtain triploid fry in Cynoglossus semilaevis Gunther. Hybridization is one of the most commonly used biological methods to induce polyploidy in fish. Wu et al. [121] crossed the female descendants of Cyprinus carpio (우)×Carassius auratus (ठ) with male mirror carp (Cyprinus carpio) and obtained triploid carp. The proportion of triploid offspring is often low and variable using these methods; therefore they are not widely used.

Interestingly, Carassius auratus gibelio is a naturally occurring triploid that differs from the other single-sex line gynogenetic species as a certain proportion is males, making them a triploid amphoteric group. When Carassius auratus gibelio eggs are activated by heterogeneous sperms, the offspring are all females. Using molecular marker technology, Gui and Zhou [122] developed different clonal strains of Carassius auratus gibelio. Using these clone lines, the researchers obtained a novel clone $\mathrm{A}^{+}$with obvious growth advantage by sexual mating between clone $\mathrm{D}$ female and clone A male in polyploid gibel carp. Genetic composition analysis showed that clone $\mathrm{A}^{+}$was a nucleocytoplasmic hybrid between clones $\mathrm{A}$ and $\mathrm{D}$, because its entire nuclear genome was from the paternal clone A and its mtDNA genome (cytoplasm) was from the maternal clone $\mathrm{D}$ [123]. Therefore, the formation of clone $\mathrm{A}^{+}$was suggested to be the androgenesis of clone A sperm in clone D ooplasm. Significantly, selected female in clone $\mathrm{A}^{+}$still possessed gynogenetic ability, and then produced a novel clone variety "CAS III" which had been approved by National Certification Committee for Aquatic Varieties. This new variety has been cultured throughout China [123].

Researchers have used heat shock to obtain tetraploid rainbow trout [124], channel catfish [125], tench (Tinea tinea L.) [126], and loach [127]. Similarly, hydrostatic pressure was used to obtain tetraploid tongue sole (Cynoglossus semilaevis. Günther) [128] and a combination of hydrostatic pressure and cold shock was used to obtain tetraploid Oreochromis spp [129] and Carassius auratus transparent colored var. (C. auratus) [130]. Zou et al. [131] successfully obtained autotetraploid Megalobrama amblycephala by heat shock inhibition of first cleavage of the zygote derived from self-crosses of Pujiang No. $1 \mathrm{M}$. amblycephala. While using hybridization to obtain tetraploid fish, Gui et al. [132] noted the occurrence of a small number of tetraploid individuals in an artificially cultured population of $C$. auratus gibelio. The chromosomes in these individuals were derived from silver crucian carp and fused with a set of haploid chromosome from $C$. carpio var. However, these authors were unsuccessful at obtaining a bisexual fertile tetraploid fish population, so these approaches have not been applied to the production of triploids.

Beginning in the 1970s, our laboratory experimented with hybridization between red crucian carp (우, $2 n=100$ ) and common carp $(ð, 2 n=100)$ and noted the presence of some fertile diploid individuals in the $\mathrm{F}_{1}$ hybrids. Using these, we obtained the $\mathrm{F}_{2}$ generation, and in the $\mathrm{F}_{3}(4 n=200$ or $2 n=4 \mathrm{X}=200$ ) we obtained tetraploid hybrids, called allotetraploids [57,64]. This allotetraploid population has a stable genetic characteristic and we have since continued breeding this to the $\mathrm{F}_{24}$ generation. Thus, we are able to mass-produce infertile triploid fish. Currently, we produce infertile triploid fish by crossing allotetraploid male carp and diploid female crucian carp. Infertile triploid carps are in demand by culturists because they have significant social, economic, and ecological benefits. The allotetraploid carp populations have heterosis of genetic stability and characteristics that are needed [57] to form a new species. Tetraploid crucian carp also provide an important research model to evaluate the origin and evolution of polyploid fish.

The red carp have 100 chromosomes whereas M. amblycephala have 48 chromosomes. Using red carp as a female parent and Megalobrama amblycephala as a male parent, we carried out a hybridization experiment [67,133]. We 
obtained fertile allotetraploid and infertile triploid $\mathrm{F}_{1}$ hybrids. The fertile allotetraploid was able to produce two types of gametes concurrently, one type having 148 chromosomes and the other having 100 chromosomes. To date, we have cultured nine generations of autotetraploid progeny by self-crossing and have formed a stable autotetraploid line. Autotetraploids $(4 n=200)$ are used to produce triploid hybrids by crossing with red carp for use in aquaculture [69]. The first generation of tetraploid crucian carp bream (우, $4 n=148$ ) was backcrossed with its female parent $M$. amblycephala $\left(\sigma^{\top}, 2 n=48\right)$ to obtain a pentaploid hybrid $(5 n=172)$. A backcross of the pentaploid with its male parent red carp yielded a new pentaploid hybrid $(5 n=198)$.

Research in our laboratory has also yielded triploid $(3 n=124)$ and tetraploid $(4 n=148)$ hybrids from distant hybridization between Carassius auratus red var. (우, $2 n=100$ ) and Xenocypris davidi ( $ð, 2 n=48)$ and diploid $(2 n=74)$, triploid $(3 n=124)$, and tetraploid $(4 n=148)$ hybrids from distant hybridization between Carassius auratus red var. (우, $2 n=100$ ) and M. amblycephala (ơ, 2n=48) [68]. In the progeny of distant hybridization between grass carp (우, $2 n=48$ ) and blunt snout bream ( $0,2 n=48)$, we detected diploid $(2 n=48)$ and triploid $(3 n=72)$ hybrids [66].

Liu [134] summarized the experiments and achievements in fish distant hybridization in about 20 years, and wrote Fish Distant Hybridization. This book systematically described the processes and mechanism of the formation of autotetraploid and allotetraploid fish, and also described the processes and mechanism of new diploid varieties by using distant hybridization and the merits and value of triploid fish in production and applications.

\subsection{Modification breeding technologies}

The essence of fish genetic breeding is a cyclic process, involving the selection or development of variable strains from stable strains, and then the culture of stable strains from variable strains. The ideal mutant strains are rapidly obtained by reasonable trait transformation methods, and decide the efficiency and effectiveness of fish genetic breeding. Transgenic breeding is an effective means of trait transformation that can be used to rapidly acquire new variant strains.

Transgenic fish are a category of fish that were developed using gene transfer technology whereby a foreign gene is incorporated into the genome of the recipient fish and it can be passed on to future generations. Fish are a relatively primitive vertebrate taxa, with large genetic plasticity and fecundity. Furthermore, the eggs can easily be developed in vitro so can be micro-manipulated.

The earliest reported study of transgenic fish was by a Chinese researcher who developed the world's first transgenic fish in 1985 [135]. Since then, the team led by Zhu has developed a number of transgenic fish models, and has laid a theoretical foundation for fish gene transfer research and development. Subsequently, a number of countries have experimented with transgenic fish, developing transgenic medaka, coho salmon, rainbow trout and others [136-139].

A feature of transgenic technology is the introduction of exogenous genes into the recipient fish. Using this approach, it is possible to obtain new varieties that have desirable and predictable traits. Traditional genetic breeding requires repeated breeding over many generations whereas transgenic technology can cut the time course of evolution and create new breeds or strains in a short time (single generation).

At present, the application of fish transgenic technology in fish genetic breeding centers around three needs. The first is the cultivation of high-yield varieties that have increased growth rate and food conversion rates. The second is the cultivation of resistant strains (disease, cold). The third is the basic study of the mechanisms of animal growth, development, reproduction and other life activities.

With respect to the cultivation of high-yielding varieties, Zhu [140-142] obtained transgenic carp that had individual growth rates 3-4 times faster than the original control. Likewise, a cooperative effort between our laboratory and the Sciences Institute of Chinese Academy of Aquatic Organisms developed transgenic allotetraploid hybrids that were transfected with the fish growth hormone gene using a microinjection technique. These transgenic tetraploids exhibit a rapid growth rate and strong disease resistance [143]. Additionally, Feng et al. [144] successfully transferred a black carp recombinant growth hormone gene into transgenic allotetraploids by microinjection. The transgenic fish had a growth rate that was 2.65 times faster than the control group. In summary, transfer of fish growth hormone genes appears to yield significant growth-promoting benefits. In addition to growth hormone genes, researchers have experimented with the transfer of genes promoting resistance to factors such as cold, disease, and hypoxia. Fletcher et al. [145] transferred an antifreeze protein gene from winter flounder (Pseudopleuronectes americanus) into Atlantic salmon, so that the Atlantic salmon had increased resistance to low temperature before entering salt water. A number of genes are known to increase disease resistance in fish, including interferon and lysozyme genes. Transfer of these genes has been associated with increased survival by improving disease resistance, resulting in improved yield [146]. Dunham et al. [147] demonstrated that transfer of the cecropin B gene to channel catfish enhanced immunity against pathogenic bacteria. Mao et al. [148] found that some genetically modified grass carp anti-aeromonas' hydrophilia capacity significantly increased by transferring recombinant plasmid containing the human lactoferrin into the grass carp. The transfer of genes coding for increased resistance appears to improve the ability of transgenic fish to cope with their environment. These new varieties will significantly improve the efficiency of fish farming. 
Transgenic breeding has been frequently used to quickly establish new variant strains. However, concerns over bio-safety/security have prevented these strains from entering the mass production application stage [139]. To address these concerns, research will likely focus on the development of transgenic sterile triploid fish. Additionally, the application of "whole fish" genes as exogenous genes for transgenosis would reduce the food safety risks of transgenic fish. To date, efforts by our laboratory and the Sciences Institute of Chinese Academy of Aquatic Organisms have resulted in two generations of transgenic triploid carp (positive fish) and non-transgenic triploid carp (negative fish), by mating between Yellow River carp (C. carpio) transfected with diploid grass carp growth hormone gene and improved allotetraploid crucian carp. We have since collected data on the growth, reproductive and developmental characteristics of these two triploid carp, providing important baseline information for the industrialization of trans-growth-hormone gene carp [149].

\section{Deficiencies and future of fish genetic breed- ing}

After years of efforts, there has been significant progress, evidenced by the establishment of hybrid, ploidy, cell nuclear transfer, chromosome engineering, and genetic engineering technologies. These efforts have significantly improved the productivity of the aquaculture industry and increased the genetic diversity of fish.

On the whole, however, good varieties of the main aquaculture fish are comparatively few. One of the primary reasons is that the contact between basic research of fish genetic breeding and the breeding practices is not close enough. How to quickly apply these new technologies to genetic breeding practices is another question. In addition, conventional cellular engineering technologies, such as distant hybridization and artificial gynogenesis, have been proved to be effective methods, but new varieties obtained by using these methods are limited, because of the demands for good conditions (larger aquaculture sites and perfect aquaculture facilities) and systematic detection methods of genetic breeding. Nevertheless, it is promising to resolve the above issues and stick to targeted research with long-term unremitting efforts in these aspects. Thus, there is a need to link basic research with industry demand and integrate the use of genetic breeding techniques into the industry. Additionally, there is a need to foster a climate of innovation to accelerate development of new technologies.

This work was supported by the Major International Cooperation Projects of the National Natural Science Foundation of China (31210103918), National Natural Science Foundation of China (31430088 and 31272651), National High Technology Research and Development Program of China (2011AA100403), Doctoral Fund of Ministry of Education of China
(20114306130001), Cooperative Innovation Center of Engineering and New Products for Developmental Biology of Hunan Province (20134486), and the Construct Program of the Key Discipline in Hunan Province and China.

1 Kause A, Ritola O, Paananen T, Wahlroos H, Mantysaan EA. Genetic trends in growth, sexual maturity and skeletal deformations, and rate of inbreeding in a breeding programme for rainbow trout (Oncorhynchus mykiss). Aquaculture, 2005, 247: 177-187

2 Neira R, Díaz NF, Gall GAE, Gallardo JA, Lhorente JP, Alert A. Genetic improvement in coho salmon (Oncorhynchus kisutch). II: Selection response for early spawning date. Aquaculture, 2006, 257: $1-8$

3 Saillant E, Dupont-Nivet M, Haffray P, Beatrice C. Estimates of heritability and genotype environment interactions for body weight in sea bass (Dicentrarchus labrax L.) raised under communal rearing conditions. Aquaculture, 2006, 254: 139-147

4 Gheyas AA, Woolliams JA, Taggart JB, Sattar MA, Das TK, McAndrew BJ, Penman DJ. Heritability estimation of silver carp (Hypophthalmichthys molitrix) harvest traits using microsatellite based parentage assignment. Aquaculture, 2009, 294: 187-193

5 Rezk MA, Smitherman RO, Williams JC, Nichols A, Kucuktas H, Dunham RA. Response to three generations of selection for increased body weight in channel catfish, Ictalurus punctatus, grown in earthen ponds. Aquaculture, 2003, 228: 69-79

6 Embody GC, Hayford CO. The advantage of rearing brook trout fingerlings from selected breeders. Trans Am Fish Soc, 1925, 55: 135-142

7 Main KL, Reynolds E. Selective breeding of fishes in Asia and the United States. In: Proceedings of a workshop in Honolulu, Hawaii. 1993, 3-7: 206-213

8 Wang HF, Liu X, Su JH, Wang GF, Wei YM. Effects of starvation and subsequent refeeding on growth and biochemical compositions of Gansu Golden Trout. J Anim Vet Adv, 2013, 12: 289-294

9 Tang SJ, Li SF, Cai WQ, Zhao Y. Microsatellite analysis of variation among wild, domesticated, and genetically improved populations of blunt snout bream (Megalobrama amblycephala). Zool Res, 2014, 35 : 108-117

10 Li SF, Tang SJ, Cai WQ. RAPD-SCAR markers for genetically improved NEW GIFT Nile Tilapia (Oreochromis niloticus niloticus L.) and their application in strain identification. Zool Res, 2010, 31: 147-53

11 Liu YG, Chen SL, Li BF, Wang ZJ, Liu ZJ. Analysis of genetic variation in selected stocks of hatchery flounder, Paralichthys olivaceus, using AFLP markers. Biochem Syst Ecol, 2005, 33: 993-1005

12 Ning Y, Liu XD, Wang ZY, Guo W, Li YY, Xie FJ. A genetic map of large yellow croaker Pseudosciaena crocea. Aquaculture, 2007, 264: 16-26

13 Zhang TS, Kong J, Liu BS, Wang QY, Cao BX, Luan S, Wang WJ. Genetic parameter estimation for juvenile growth and upper thermal tolerance in turbot (Scophthalmus maximus Linnaeus). Acta Oceanol Sin, 2014, 33: 106-110

14 Hong WS, Zhang QY. Review of captive bred species and fry production of marine fish in China. Aquaculture, 2003, 227: 305-318

15 Yang WJ, Kang XL, Yang QF, Lin Y, Fang MY. Review on the development of genotyping methods for assessing farm animal diversity. Journal of Animal Science and Biotechnology, 2013, 4: 2

16 Arif IA, Khan HA. Molecular markers for biodiversity analysis of wildlife animals: a brief review. Anim Bioiv Conserv, 2009, 32: 9-17

17 Jander G. Gene identification and cloning by molecular marker mapping. Methods Mol Biol, 2006, 323: 115-126

18 Luo ZW, Hackett CA, Bradshaw JE, McNicol JW, Milbourne D. Construction of a genetic linkage map in tetraploid species using molecular markers. Genetics, 2001, 157: 1369-1385

19 Montaldo HH, Meza-Herrera CA. Use of molecular markers and major genes in the genetic improvement of livestock. Electron J Biotechn, 1998, 1: 1-7 
20 Agarwal M, Shrivastava N, Padh H. Advances in molecular marker techniques and their applications in plant sciences. Plant Cell Rep, 2008, 27: 617-631

21 Postlethwait JH, Johnson SL, Midson CN, Talbot WS, Gates M, Ballinger EW, Africa D, Andrews R, Carl T, Eisen JS. A genetic linkage map for the zebrafish. Science, 1994, 264: 699-703

22 Naruse K, Tanaka M, Mita K, Shima A, Postlethwait J, Mitani H. A medaka gene map: the trace of ancestral vertebrate protochromosome revealed by comparative gene mapping. Genome Res, 2004, 14: 820-828

23 Kai W, Kikuchi K, Fujita M, Suetake H, Fujiwara A, Yoshiura Y, Ototake M, Venkatesh B, Miyaki K, Suzuki Y. A genetic linkage map for the tiger pufferfish, Takifugu rubripes. Genetics, 2005, 171: 227-238

24 Walter RB, Rains JD, Russell JE, Guerra TM, Daniels C, Johnston DA, Kumar J, Wheeler A, Kelnar K, Khanolkar VA, Williams EL, Hornecker JL, Hollek L, Mamerow MM, Pedroza A, Kazianis S. A microsatellite genetic linkage map for Xiphophorus. Genetics, 2004, 168: 363-372

25 Peichel CL, Nereng KS, Ohgi KA, Cole BLE, Colosimo PF, Buerkle CA, Schluter D, Kingsley DM. The genetic architecture of divergence between three spine stickleback species. Nature, 2001, 414: 901-905

26 Young WP, Wheeler PA, Coryell VH. A detailed linkage map of rainbow trout produced using doubled haploids. Genetics, 1998, 148: 839-850

27 Lee BY, Lee WJ, Streelman JT, Carleton KL, Howe AE, Hulata G, Slettan A, Stern JE, Terai Y, Kocher TD. A second generation genetic linkage map of tilapia (Oreochromis spp.). Genetics, 2005, 170: 237-244

28 Liu ZJ, Cordes JF. DNA marker technologies and their applications in aquaculture genetics. Aquaculture, 2004, 238: 1-37

29 Chauhan T, Rajiv K. Molecular markers and their applications in fisheries and aquaculture. Adv Biosci Biotech, 2010, 1: 281-291

30 Laghari MY, Lashari P, Zhang X, Xu P, Narejo NT, Xin B, Zhang Y, Sun X. QTL mapping for economically important traits of common carp (Cyprinus carpio L.). J Appl Genet, 2014, doi: 10.1007/s13353014-0232-y

31 Gui JF, Zhu ZY. Molecular basis and genetic improvement of economically important traits in aquaculture animals. Chin Sci Bull, 2012, 57: 1751-1760

32 Jang SH, Liu H, Su JG, Dong F, Xiong F, Liao LJ, Wang YP, Zhu ZY. Construction and characterization of two bacterial artificial chromosome libraries of grass carp. Mar Biotechnol, 2010, 12: 261-266

33 Geng FS, Zhou L, Gui JF. Construction and characterization of a BAC library for Carassius auratus gibelio, a gynogenetic polyploid fish. Anim Genet, 2005, 36: 535-536

34 Zhang JJ, Shao CW, Zhang LY, Liu K, Gao FT, Dong ZD, Xu P, Chen SL. A first generation BAC-based physical map of the half-smooth tongue sole (Cynoglossus semilaevis) genome. BMC Genomics, 2014, 15: 215

35 Zhao SY. Genomics and life sciences industry. Chin Sci Bull, 1999, 11: $1-5$

36 Sarropoulou E, Nousdili D, Magoulas A, Kotoulas G. Linking the genomes of nonmodel teleosts through comparative genomics. Mar Biotechnol, 2008, 10: 227-233

37 Star B, Nederbragt AJ, Jentoft S, Grimholt U, Malmstrom M, Gregers TF, Rounge TB, Paulsen J, Solbakken MH, Sharma A, Wetten OF, Lanzen A, Winer R, Knight J, Vogel JH, Aken B, Andersen Q, Lagesen K, Tooming-Klunderud A, Edvardsen BO, Moum T, Skage M, Berg PR, Gjqen T, Kuhl H, Thorsen J, Malde K, Reinhardt R, Du L, Johansen SD, Searle S, Lien S, Nilsen F, Jonassen I, Omholt SW, Stenseth NC, Jakobsen KS. The genome sequence of Atlantic cod reveals a unique immune system. Nature, 2011, 477: 207-210

38 Chen SL, Zhang GJ, Shao CW, Huang QF, Liu G, Zhang P, Song WT, An N, Chalopin D, Volff JN, Hong YH, Li QY, Sha ZX, Zhou HL, Xie MS, Yu QL, Liu Y, Xiang H, Wang N, Wu K, Yang CG,
Zhou Q, Liao XL, Yang LF, Hu QM, Zhang JL, Meng L, Jin LJ, Tian YS, Lian JM, Yang JF, Miao GD, Liu SS, Liang Z, Yan F, Li YZ, Sun B, Zhang H, Zhang J, Zhu Y, Du M, Zhao YW, Schartl M, Tang QS, Wang J. Whole-genome sequence of a flatfish provides insights into ZW sex chromosome evolution and adaptation to a benthic lifestyle. Nat Genet, 2014, 46: 253-260

39 Zhang GF, Fang XD, Guo XM, Li L, Luo RB, Xu F, Yang PC, Zhang LL, Wang XT, Qi HG, Xiong ZQ, Que HY, Xie YL, Holland PWH, Paps J, Zhu YB, Wu FC, Chen YX, Wang JF, Peng CF, Meng J, Yang L, Liu J, Wen B, Zhang N, Huang ZY, Zhu QH, Feng Y, Mount A, Hedgecock D, Xu Z, Liu YJ, Domazet-Loso T, Du YS, Sun XQ, Zhang SD, Liu BH, Cheng PZ, Jiang XT, Li J, Fan DD, Wang W, Fu WJ, Wang T, Wang B, Zhang JB, Peng ZY, Li YX, Li N, Wang JP, Chen MS, He Y, Tan FJ, Song XR, Zheng QM, Huang RL, Yang HL, Du XD, Chen L, Yang M, Gaffney PM, Wang S, Luo LH, She ZC, Ming Y, Huang W, Zhang S, Huang BY, Zhang Y, Qu T, Ni PX, Miao GY, Wang JY, Wang Q, Steinberg CEW, Wang HY, Li N, Qian LM, Zhang GJ, Li YR, Yang HM, Liu X, Wang J, Yin Y, Wang J. The oyster genome reveals stress adaptation and complexity of shell formation. Nature, 2012, 490: 49-54

40 Xu P, Zhang XF, Wang XM, Li JT, Liu GM, Kuang YY, Xu J, Zheng XH, Ren LF, Wang GL, Zhang Y, Huo LH, Zhao ZX, Cao DC, Lu CY, Li C, Zhou Y, Liu ZJ, Fan ZH, Shan GL, Li XG, Wu SX, Song LP, Hou GY, Jiang YL, Jeney Z, Yu D, Wang L, Shao CJ, Song L, Sun J, Ji PF, Wang J, Li Q, Xu LM, Sun FY, Feng JX, Wang CH, Wang SL, Wang BS, Li Y, Zhu YP, Xue W, Zhao L, Wang JT, Gu Y, Lv WH, Wu KJ, Xiao JF, Wu JY, Zhang Z,Yu J, Sun XW. Genome sequence and genetic diversity of the common carp, Cyprinus carpio. Nat Genet, 2014, doi: 10.1038/ng.3098

41 Devlin R, Nagahama Y. Sex determination and sex differentiation in fish: an overview of genetic, physiological, and environmental influences. Aquaculture, 2002, 208: 191-364

42 Pandian TJ, Sheela SG. Hormonal induction of sex reversal in fish. Aquaculture, 1995, 138: 1-22

43 Piferrer F. Endocrine sex control strategies for the feminization of teleost fish. Aquaculture, 2001, 197: 229-281

44 Yamamoto T. Progeny of artificially induced sex-reversals of male genotype (XY) in the medaka (Oryzias latipes) with special reference to YY male. Geneties, 1955, 40: 406-429

45 Guerrero RD. Use of Androgens for the production of all male Tilapia aurea (steindacher). Trans Amer Fish Soc, 1975, 104: 342-348

46 Liu SJ, Yao ZZ, Wang YQ. Sex hormone induction of sex reversal in the teleost clarias lazera and evidence for female homogmety and male heterogamety. J Exp Zool, 1996, 276: 432-438

47 Liu SJ, Yao ZZ. Self-fertilization of hermaphrodites of the teleost Clarias lazera after oral administration of 17- $\alpha$-methyltestosterone and their offspring. J Exp Zool, 1995, 273: 527-532

48 Chen RD, Huang WY, Wu QJ, Ye YZ. Cultivation and breeding effects of all-female carp (in Chinese). Reserv Fish, 1990, 3: 21-23

49 Luo KK, Xiao J, Liu SJ, Wang J, He WG, Hu J, Qin QB, Zhang C, Tao M, Liu Y. Massive production of all-female diploids and triploids in the crucian carp. Int J Biol Sci, 2011, 7: 487-495

50 Liu HQ, Cui SQ, Hou CC, Xu J, Chen HX. YY supermale generated gynogenetically from XY female in Pelteobagrus fulvidraco (Richardson) (in Chinese). Acta Hydrobiol Sin, 2007, 31: 718-725

51 Wang D, Mao HL, Chen HX, Liu HQ, Gui JF. Isolation of Y- and $\mathrm{X}$-linked SCAR markers in yellow catfish and application in the production of all-male populations. Anim Genet, 2009, 40: 978-981

52 Dan C, Mei J, Wang D, Gui JF. Genetic differentiation and efficient sex-specific marker development of a pair of Y- and X-linked markers in Yellow Catfish. Int J Biol Sci, 2013, 9: 1043-1049

53 Hulata G. A review of genetic improvement of the common carp (Cyprinus carpio L.) and other hybrids by crossbreeding, hybridization and selection. Aquaculture, 1995, 129: 143-155

54 Kirpichnikov VS, Ilyasov JI, Shart LA, Vikhman AA, Ganchenko MV, Ostashevsky AL, Simonov VM, Tikhonov GF, Tjurin VV. Selection of krasnodar common carp (Cyprinus carpio L.) for resistance to dropsy: principal results and prospects. Aquaculture, 1993, 111: 
$7-20$

55 Zhou J, Wu Q, Wang Z, Ye Y. Genetic variation analysis within and among six varieties of common carp (Cyprinus carpio L.) in China using microsatellite markers. Rus J Genet, 2004, 40: 1144-1148

56 Li SF, He XJ, Han FJ. Third-fifth generation selective evaluation of GIFT strain Nile tilapia. Beijing: World Aquaculture, 2002. 410

57 Liu SJ. Distant hybridization leads to different ploidy fishes. Sci China Life Sci, 2010, 53: 416-425

58 Schwartz FJ. World literature to fish hybrids with an analysis by family, species and hybrid: supplement. NOAA Technical Report NMFS SSRF, 1981, 2: 750

59 Zhang ZH, Chen J, Li L, Tao M, Zhang C, Qin QB, Xiao J, Liu Y, Liu SJ. Research advances in animal distant hybridization. Science China Life Sci, 2014, 44: 161-174

60 Beck ML, Biggers CJ, Dupree HK. Karyological analysis of $\mathrm{Hy}$ pophthalmichthys molitrix, Aristichthys nobilis and their $\mathrm{F}_{1}$ hybrid. Trans Am Fish Soc, 1980, 109: 433-438

61 Sulaiman AH. Toxicity of malathion to red tilapia (Hybrid Tilapia mossambica $\times$ Tilapia nilotica): behavioural, histopathological anti-cholinesterase studies. Mal Appl Biol (Malaysia), 1989, 18: $163-170$

62 Harms CA, Kennedy-Stoskopf S, Horne WA, Fuller FJ, Tompkins WA. Cloning and sequencing hybrid striped bass (Morone saxatilis $\times$ M. chrysops) transforming growth factor-beta (TGF-beta), and development of a reverse transcription quantitative competitive polymerase chain reaction (RT-qcPCR) assay to measure TGF-beta mRNA of teleost fish. Fish Shellfish Immunol, 2000, 10: 61-85

63 Sui J, Liu QH, Xiao ZZ, Ma DY, Xu SH, He T, Liu YF, Xiao YS, Li J. The viability, melanophore and embryo genesis of first- and second-generation hybrids between Paralichthys olivaceus and P. dentatus. Mar Biol Res, 2013, 9: 220-226

64 Liu SJ, Liu Y, Zhou GJ, Zhang XJ, Luo C, Feng H, He XX, Zhu GH, Yang $H$. The formation of tetraploid stocks of red crucian carp $\times$ common carp hybrids as an effect of interspecific hybridization. Aquaculture, 2001, 192: 171-186

65 Hu J, Liu SJ, Xiao J, Zhou Y, You CP, He WG, Zhao RR, Song C, Liu Y. Characteristics of diploid and triploid hybrids derived from female Megalobrama amblycephala Yih $\times$ male Xenocypris davidi Bleeker. Aquaculture, 2012, (364-365): 157-164

66 He WG, Xie LH, Li TL, Liu SJ, Xiao J, Hu J, Wang J, Qin QB, Liu $\mathrm{Y}$. The formation of diploid and triploid hybrids of female grass carp $\times$ male blunt snout bream and their $5 \mathrm{~S}$ rDNA analysis. BMC Genetics, 2013, 14: 110

67 Liu SJ, Qin QB, Xiao J, Lu W, Shen J, Li W, Liu J, Duan W, Zhang C, Tao M, Zhao R, Yan J, Liu Y. The formation of the polyploid hybrids from different subfamily fish crossing and its evolutionary significance. Genetics, 2007, 176: 1023-1034

68 He WG, Qin QB, Liu SJ, Li TL, Wang J, Xiao J, Xie LH, Zhang C, Liu Y. Organization and variation analysis of $5 \mathrm{~S}$ rDNA in different ploidy-level hybrids of red crucian carp $\times$ topmouth culter. PLoS One, 2012, 6: e38976

69 Qin QB, Wang YD, Wang J, Dai J, Xiao J, Hu FZ, Luo KK, Tao M, Zhang C, Liu Y, Liu SJ. The autotetraploid fish derived from hybridization of Carassius auratus red var. (female) $\times$ Megalobrama amblycephala (male). Biol Reprod, 2014, 91: 93, 1-11

70 Tung TC, Wu SQ, Ye YF, Yan SY, Du M, Lu DY. Nuclear transplantation of fish. Sci Sin B, 1963, 7: 60-61

71 Chen HX, Yi YL, Chen MR, Yang XQ. Studies on the developmental potentiality of cultured cell nuclei of fish (in Chinese). Acta Hydrobiol Sin, 1986, 10: 1-7

72 Lee KY, Huang HG, Ju BS, Yang Z, Lin S. Cloned zebrafish by nuclear transfer from long-term cultured cells. Nature, 2002, 20: 795-799

73 Yan SY. A historical review and some comments on the nuclear transplantation in fish (in Chinese). Chin J Biotechnol, 2000, 16: 541-547

74 Yu LN, Zuo WG, Fang YL, Zheng WD. Cell-engineering grass carp produced by the combination of electric fusion and nuclear trans- plantation (in Chinese). J Fish China, 1996, 20: 312-318

75 Yan SY. The nucleo-cytoplasmic interaction as revealed by nuclear transplantation in fish. In: Gytoplasm Organization System. New York: McGraw-Hill Pub. Co., 1989. 61-81

76 Yu LN, Yang YQ, Liu L, Zheng WD, Fang YL. Study on the fish cell nucleus transplant with egg not take off the nucleus as a receptor (in Chinese). Freshw Fish, 1989, 3: 3-7

77 Lin LT, Xia SL, Zhu XP. Studies on nuclear transplantation of somatic cells in teleost. Zool Res, 1996, 17: 337-340

78 Liu HQ, Yi YL, Chen HX. The birth of the androgenetic homozygous diploid loach (in Chinese). Acta Hydrobiol Sin, 1987, 11: 241-246

79 Tajima A, Naito M, Yasuda Y, Kuwana T. Production of germ line chimera by transfer of primordial germ cells in the domestic chicken (Gallus domesticus). Theriogenology, 1993, 40: 509-519

80 Lee YM, Jung JG, Kim JN, Park TS, Kim TM, Shin SS, Kang DK, Lim JM, Han JY. A testis-mediated germline chimera production based on transfer of chicken testicular cells directly into heterologous testes. Biol Reprod, 2006, 75: 380-386

81 Hill JR, Dobrinski I. Male germ cell transplantation in livestock. Reprod Fertil Dev, 2006, 18: 13-18

82 Dobrinski I. Germ cell transplantation and testis tissue xenografting in domestic animals. Anim Reprod Sci, 2005, 89: 137-145

83 Takeuchi Y, Yoshizaki G, Takeuchi T. Generation of live fry from intraperitoneally transplanted primordial germ cells in rainbow trout. Biol Reprod, 2003, 69: 1142-1149

84 Hong YH, Liu T, Zhao H, Xu H, Wang W, Liu R, Chen T, Deng J, Gui J. Establishment of a normal medakafish spermatogonial cell line capable of sperm production in vitro. Proc Natl Acad Sci USA, 2004, 101: 8011-8016

85 Okutsu T, Suzuki K, Takeuchi Y, Takeuchi T, Yoshizaki G. Testicular germ cells can colonize sexually undifferentiated embryonic gonad and produce functional eggs in fish. Proc Natl Acad Sci USA, 2006, 103: 2725-2729

86 Yi MS, Hong N, Hong YH. Generation of medaka fish haploid embryonic stem cells. Science, 2009, 326: 430-433

87 Yi MS, Hong N, Li ZD, Yan Y, Wang D, Zhao H, Hong YH. Medaka fish stem cells and their applications. Sci China Life Sci, 2010, 53: 426-434

88 Nobrega RH, Greebe CD, Kant HX, Bogerd J, Franca LR, Schulz RW. Spermatogonial stem cell niche and spermatogonial stem cell transplantation in zebrafish. PLoS One, 2010, 5: e12808

89 Takeuchi Y, Yoshizaki G, Takeuchi T. Surrogate broodstock produces salmonids. Nature, 2004, 430: 629-630

90 Majhi SK, Hattori RS, Yokota M, Watanabe S, Strussmann CA. Germ cell transplantation using sexually competent fish: an approach for rapid propagation of endangered and valuable germlines. PLoS One, 2009, 4: e6132

91 Okutsu T, Shikina S, Kanno M, Takeuchi Y, Yoshizaki G. Production of trout offspring from triploid salmon parents. Science, 2007, 317: 1517

92 Komen H, Thorgaard GH. Androgenesis, gynogenesis and the production of clones in fishes: a review. Aquaculture, 2007, 269: 150-173

93 Liu J, Yang G. Changes in copper content of allogynogenetic silver crucian carp after application of copper sulfate to fishponds. Isr J Aquacult-Bamid, 2009, 61: 351-355

94 Liu SJ, Qin QB, Wang YQ, Zhang H, Zhao R, Zhang C, Wang J, Li W, Chen L, Xiao J, Luo K, Tao M, Duan W, Liu Y. Evidence for the formation of the male gynogenetic fish. Mar Biotechnol, 2010, 12: 160-172

95 Felip A, Zanuy S, Carrillo M, Piferrer F. Induction of triploidy and gynogenesis in teleost fish with emphasis on marine species. Genetica, 2001, 111: 175-195

96 Komen J, Wiegertjes GF, Van Ginneken VJT, Eding EH, Richter CJJ Gynogenesis in common carp (Cyprinus carpio L.) III. The effects of inbreeding on gonadal development of heterozygous and homozygous gynogenetic offspring. Aquaculture, 1992, 104: 51-66

97 Fopp-Bayat D, Kolman R, Woznicki P. Induction of meiotic gyno- 
genesis in sterlet (Acipenser ruthenus) using UV-irradiated bester sperm. Aquaculture, 2007, 264: 54-58

98 Morgan AJ, Murashige R, Woolridge CA, Luckenbach JA, Watanabe WO, Borski RJ, Godwin J, Daniels HV. Effective UV dose and pressure shock for induction of meiotic gynogenesis in southern flounder Paralichthys lethostigma using black seabass (Centropristis striata) sperm. Aquaculture, 2006, 259: 290-299

99 Piferrer F, Cal RM, Gsmez C, Alvarez-Blazquez B, Castro J, Martinez P. Induction of gynogenesis in the turbot (Scophthalmus maxi$m u s)$ : effects of UV irradiation on sperm motility, the Hertwig effect and viability during the first 6 months of age. Aquaculture, 2004, 238: 403-419

100 Rougeot C, Ngingo JV, Gillet L, Vanderplasschen A, Melard C. Gynogenesis induction and sex determination in the Eurasian perch, Perca fluviatilis. Aquaculture, 2005, 43: 411-415

101 Lin F, Dabrowski K. Induction of gynogenesis in muskellunge (Esox masquinongy). Aquaculture, 1995, 137: 153-154

$102 \mathrm{Li} \mathrm{Q}$, Kijima A. Microsatellite analysis of gynogenetic families in the Pacific oyster, Crassostrea gigas. J Exp Mar Biol Ecol, 2006, 331: $1-8$

103 Sun YD, Tao M, Liu SJ, Zhang C, Duan W, Shen JM, Wang J, Zeng $\mathrm{C}$, Long Y, Liu Y. Induction of gynogenesis in red crucian carp using spermatozoa of blunt snout bream. Prog Nat Sci, 2007, 17: 163-167

104 Sun YD, Zhang C, Liu SJ, Tao M, Zeng C, Liu Y. Induction of gynogenesis in Japanese crucian carp (Carassius cuvieri). Acta Genetica Sinica, 2006, 33: 405-412

105 Zhang H, Liu SJ, Zhang C, Tao M, Peng L, You CP, Xiao J, Zhou Y, Zhou G, Luo KK, Liu Y. Induced gynogenesis in Grass Carp (Ctenopharyngodon idellus) using irradiated sperm of allotetraploid hybrids. Mar Biotechnol, 2010, 13: 1017-1026

106 Liu SJ, Duan W, Tao M, Zhang C, Sun YD, Shen J, Wang J, Luo KK, Liu Y. Establishment of the diploid gynogenetic hybrid clonal line of red crucian carp×common carp. Sci China Ser C-Life Sci, 2007, 50: 186-193

107 Xiao J, Zou TM, Chen YB, Chen L, Liu SJ, Tao M, Zhang C, Zhao RR, Zhou Y, Long Y, You CP, Yan JP, Liu Y. Coexistence of diploid, triploid and tetraploid crucian carp (Carassius auratus) in natural waters. BMC Genetics, 2011, 12: 20

108 Stanley JG. Production of hybrid, androgenetic and gynogenetic grass carp and carp. T Am Fish Soc, 1976, 105: 10-16

109 Arai K, Onozato H, Yamazaki F. Artificial androgenesis induced with gamma irradiation in masou salmon (oncorhynchus masou). Bull Fac Fish Hokkaido Univ, 1979, 30: 181-186

110 Araki K, Shinma H, Nagoya H, Nakayama I, Onozato H. Androgenetic diploids of rainbow trout (Oncorhynchus mykiss) produced by fused sperm. Can J Fish Aquat Sci, 1995, 52: 892-896

111 Babiak I, Dobosz S, Goryczko K, Kuzminski H, Brzuzan P, Ciesielski S. Androgenesis in rainbow trout using cryopreserved spermatozoa: the effect of processing and biological factors. Theriogenology, 2002, 57: 29249

112 Thorgaard GH, Scheerer PD, Hershberger WK, Myers JM. Androgenetic rainbow trout produced using sperm from tetraploid males show improved survival. Aquaculture, 1990, 85: 215-221

113 Arai K, Ikeno M, Suzuki R. Production of androgenetic diploid loach Misgurnus anguillicaudatus using spermatozoa of natural tetraploids. Aquaculture, 1995, 137: 131-138

114 Fujimoto T, Yasui GS, Hayakawa M, Sakao S, Yamaha E, Arai K. Reproductive capacity of neo-tetraploid loaches produced using diploid spermatozoa from a natural tetraploid male. Aquaculture, 2010, 308: s133-139

115 Sun YD, Zhang C, Liu SJ, Duan W, Liu Y. Induced interspecific androgenesis using diploid sperm from allotetraploid hybrids of common carp $\times$ red crucian carp. Aquaculture, 2007, 264: 47-53

116 Duan W, Qin QB, Chen S, Liu SJ, Wang J, Zhang C, Sun YD, Liu Y. The formation of improved tetraploid population of red crucian carp $\times$ common carp hybrids by androgenesis. Sci China Ser C-Life Sci, 2007, 50: 753-761

117 Song C, Liu SJ, Xiao J, He WG, Zhou Y, Qin QB, Zhang C, Liu Y.
Polyploid organisms. Sci China Life Sci, 2012, 55: 301-311

118 Benfey TJ. The physiology and behavior of triploid fishes. Rev Fish Sci, 1999, 1: 39-67

119 Gui JF, Xiao WH, Liang SC, Jiang YG. Preliminary study on the cytological mechanism of triploidy and tetraploidy induced by hydrostatic pressure shock in transparent colored crucian carp (in Chinese). Acta Hydrobiol Sin, 1995, 19: 49-55

120 Li WL, Xu Y, Deng H, Chen SL, Xie MS, Ji XS. Induction and identification of artificial triploid fry in Cynoglossus semilaevis (in Chinese). J Fish China, 2011, 35: 925-931

121 Wu C, Ye Y, Chen R, Liu X. An artificial multiple triploid carp and its biological characteristics. Aquaculture, 1993, 111: 255-262

122 Gui JF, Zhou L. Genetic basis and breeding application of clonal diversity and dual reproduction modes in polyploid Carassius auratus gibelio. Sci China Life Sci, 2010, 53: 409-415

123 Wang ZW, Zhu HP, Wang D, Jiang FF, Guo W, Zhou L, Gui JF. A novel nucleo-cytoplasmic hybrid clone formed via androgenesis in polyploid gibel carp. BMC Res Notes, 2011, 4: 82

124 Chourrout D. Tetraploidy induced by heat shocks in the rainbow trout (Salmo gairdneri R.). Reprod Nutr Dev, 1982, 22: 569-574

125 Bidwell CA, Chrisman CL, Libey G. Polyploidy induced by heat shock in channel catfish. Aquaculture, 1985, 51: 25-32

126 Flajshans M, Linhart O, Kvasnicka P. Genetic studies of tench (Tinea tinea L.): induced triploidy and tetraploidy and first performance data. Aquaculture, 1993,113: 301-312

127 Nam YK, Choi GC, Park DJ, Kim DS. Survival and growth of induced tetraploid mud loach. Aquacult Int, 2001, 9: 61-71

128 Li WL, Chen SL, Ji XS, Xie MS, Xu Y, Deng H. Induction and identification of tetraploid fry in Cynoglossus semilaevis (in Chinese). J Fish Sci China, 2012, 19: 196-201

129 Myers JM. Tetraploid induction in Oreochromis spp. Aquaculture, 1986, 57: 281-287

130 Gui JF, Sun JM, Liang SC, Huang WY, Jiang YG. Studies on genome manipulation in fish II. Tetraploidy induced by hydrostatic pressure treatment and a combination of hydrostatic pressure and cold treatments in transparent colored crucian carp (in Chinese). Acta Hydrobiol Sin, 1991, 15: 333-341

131 Zhu HP, Gui JF. Identification of genome organization in the unusual allotetraploid form of Carassius auratus gibelio. Aquaculture, 2007, 265: 109-117

132 Zou SM, Li SF, Cai WQ, Zhao JL, Yang HY. Establishment of fertile tetraploid population of blunt snout bream (Megalobrama amblycephala). Aquaculture, 2004, 238: 155-164

133 Qin QB, He WG, Liu SJ, Wang J, Xiao J, Liu Y. Analysis of 5S rDNA organization and variation in polyploid hybrids from crosses of different fish subfamilies. J Exp Zool (Mol Dev Evol), 2010, 314 : 403-411

134 Liu SJ. Fish Distant Hybridization (in Chinese). Beijing: Science Press, 2015

135 Zhu ZY, Li G, He L, Chen S. Novel gene transfer into fertilized eggs of gold fish (Carassius auratus L.1758). Z Angew Ichthyol, 1985, 1: 31-34

136 Houdebine LM, Chourrout D. Transgenesis in fish. Experientia, 1991, 47: 891-897

137 Rembold M, Lahiri K, Foulkes NS, Wittbrodt J. Transgenesis in fish: efficient selection of transgenic fish by co-injection with a fluorescent reporter construct. Nat Prot, 2006, 1: 1133-1139

138 Devlin RH. Production and evaluation of transgenic fish for aquaculture. Australas Biotechnol, 1998, 8: 222-226

139 Maclean N, Laight RJ. Transgenic fish: an evaluation of benefits and risks. Fish Fish, 2000, 1: 146-172

$140 \mathrm{Fu} \mathrm{C}, \mathrm{Hu}$ W, Wang Y, Zhu Z. Developments in transgenic fish in the People's Republic of China. Rev Sci Tech Off Int Epiz, 2005, 24 : 299-307

141 Fu C, Cui Y, Hung SSO, Zhu Z. Growth and feed utilization by $\mathrm{F}_{4}$ human growth hormone transgenic carp fed diets with different protein levels. J Fish Biol, 1998, 53: 115-129 
142 Wu G, Sun Y, Zhu ZY. Growth hormone gene transfer in common carp. Aquat Living Resour, 2003,16: 416-420

143 Feng H, Zeng ZQ, Liu SJ, Zhang XJ, Zhou GJ, Li JZ, Liu Y, Wang YP, Chen SP, Hu W, Zhu ZY. Studies of F1 of transgenic allotraploid hybrids of Carassius auratus red var. (우)×Cyprinus carpio (ठ) (in Chinese). Acta Genet Sin, 2002, 29: 434-437

144 Feng H, Fu YM, Luo J, Wu H, Liu Y, Liu SJ. Black carp GH gene transgenic allotetraploid hybrids of Carassius auratus red var. (우)×Cyprinus carpio ( $\left.{ }^{\top}\right)$. Sci China Life Sci, 2011, 41: 202-209

145 Hew CL, Davies PL, Fletcher G. Antifreeze protein gene transfer in Atlantic salmon. Mol Mar Biol Biotechnol, 1992, 1: 309-317

146 Dunham RA. Transgenic fish resistant to infectious diseases, their risk and prevention of escape into the environment and future candi- date genes for disease transgene manipulation. Comp Immunol Microbiol Infect Dis, 2009, 32: 139-161

147 Dunham RA, Warr GW, Nichols A, Duncan PL, Argue B, Middleton D, Kucuktas H. Enhanced bacterial disease resistance of transgenic channel catfish, Ictalarus punctatus, possessing cecropin genes. Mar Biotechnol, 2002, 4: 338-344

148 Mao WF, Wang YP, Wang WB, Wu B, Feng JX, Zhu ZY. Enhanced resistance to Aeromonas hydrophila infection and enhanced phagocytic activities in human lactoferrin-transgenic grass carp (Ctenopharyngodon idellus). Aquaculture, 2004, 242: 93-103

149 Yu F, Xiao J, Liang XY, Liu SJ, Zhou GJ, Luo KK, Liu Y, Hu W, Wang YP, Zhu ZY. Rapid growth and sterility of growth hormone gene transgenic triploid carp. Chin Sci Bull, 2011, 56: 1679-1684

Open Access This article is distributed under the terms of the Creative Commons Attribution License which permits any use, distribution, and reproduction in any medium, provided the original author(s) and source are credited. 